\title{
INFLUENCE OF THE COMPOSITION OF HYDROCHLORIDE POLYHEXAMETYLENEGUANIDINE WITH SURFACTANTS ON GROWTH Pseudomonadaceae AND Enterobacteriaceae BACTERIUM
}

\author{
S.Sh. Kumargaliyeva, O.A. Esimova, G.D. Isenova, K. Kokurov, K.B. Musabekov
}

Bactericidal activity of compositions of a hydrochloride polyhexametyleneguanidine with anionic (dodecyl sulfate sodium), cationic (bromide cetylpyrites) and nonionogen (Tvin-80) surface-active substances in relation to bacteria of families Pseudomonadaceae (kinds of sorts Pseudomonas) and Enterobacteriaceae (kinds of sort Erwinia) is investigated

\section{УДК 547.8+543.422.25}

\section{ВОССТАНОВЛЕНИЕ 1-МЕТИЛ-2-ФЕНИЛДЕКАГИДРОХИНОЛИН-4-ОНА}

\author{
О.Т. Жилкибаев
}

\section{КазНУ имени аль-Фараби, Алматы, Республика Казахстан, zhilkibaevoral@mail.ru}

Изучена стереохимия восстановления 1-метил-2е-фенил-транс-декагидро-хинолин-4-она в различных условиях: востановление натрием в этаноле в соответствии с механизмом этой реакции дает в основном экваториальный спирт; с боргидридом натрия и каталитическом гидрировании - образуется смесь аминоспиртов с преобладанием экваториального эпимера; восстановление аминокетона изопропилатом алюминия протекает с обычной для этого метода направленностью и приводит к преимущественному образованию аксиального спирта.

Гидроксильные производные насыщенных циклических систем широко распространены среди различных классов природных соединений (стероиды, алкалоиды, ксантоспермины, терпены и др.). От стерической направленности гидроксильной группы в этих соединениях в значительной мере зависят и физиологическая активность и химические свойства. С целью исследования влияния метильной группы на направленность реакции и на биологическую активность, нами было изучено восстановление 1-метил-3e-фенилдекагидрохинолин-4-она (1) в различных условиях [1-3].

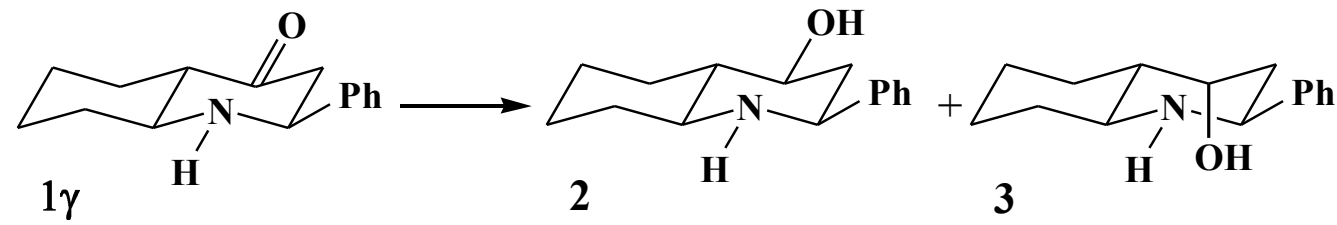

Таблица 1. Условия восстановления (1) и выходы эпимерных спиртов $(\underline{2}, \underline{3})$

\begin{tabular}{|c|c|c|c|c|c|}
\hline \multirow[t]{2}{*}{ Соединение } & \multirow{2}{*}{$\begin{array}{c}\text { Восстанавливающий } \\
\text { реагент }\end{array}$} & \multirow[t]{2}{*}{ Растворитель } & \multirow{2}{*}{$\begin{array}{c}\text { Общий } \\
\text { выход, \% }\end{array}$} & \multicolumn{2}{|c|}{ Соотнош. эпимеров, $\%$} \\
\hline & & & & 2 (экв. $\mathrm{OH}$ ) & 3 (акс. $\mathrm{OH}$ ) \\
\hline \multirow{4}{*}{$\underline{1}$} & $\mathrm{Na}+$ этанол & этанол & 81,3 & 86,4 & 13,6 \\
\hline & $\mathrm{NaBH}_{4}$ & $i$-пропанол & 91,4 & 82,3 & 17,7 \\
\hline & $\mathrm{H}_{2} / \mathrm{Ni}-\mathrm{Re}$ & этанол & 95,0 & 79,7 & 20,3 \\
\hline & $\mathrm{Al}\left(i-\mathrm{OC}_{3} \mathrm{H}_{7}\right)_{3}$ & $i$-пропанол & 78,8 & 31,9 & 68,11 \\
\hline
\end{tabular}

Вторичные спирты $\underline{\mathbf{2}}$ и $\underline{\mathbf{3}}$ были синтезированы восстановлением $\underline{\mathbf{1}}$ натрием в спирте, боргидридом натрия, каталитическим гидрированием и изопропилатом натрия - которые протекают, как правило, стереоизбирательно и отличаются высокими выходами (табл. 1). Восстановление натрием в спирте $\underline{1}$ проходит стереонаправленно и приводит к образованию смеси эпимерных вторичных спиртов $\underline{\mathbf{2}}$ и $\underline{\mathbf{3}}$ с преобладанием изомера $\underline{\mathbf{2}}$ (85,7\% от общего количества смеси изомеров) и небольшого количества его эпимера $\underline{\mathbf{3}}$ (14,3\% по ГЖХ). При восстановлении боргидридом натрия с выходом $90,8 \%$ образуется смесь аминоспиртов $\underline{\mathbf{2}}$ и $\underline{\mathbf{3}}$ с преобладанием $(80,8 \%$ от общего количества смеси изомеров) изомера $\underline{\mathbf{2}}$ и небольшого количества его эпимера $\underline{\mathbf{3}}(16,1 \%)$. При каталитическом гидрировании также образуется смесь эпимеров $\underline{\mathbf{2}}$ и $\underline{\mathbf{3}}$ с преимущественным образованием изомера $\underline{\mathbf{2}}$ $(78,6 \%)$ и $21,3 \%$ - изомера $\underline{\mathbf{3}}$. При восстановлении изопропилатом алюминия в абсолютном 
изопропаноле выход смеси спиртов 2 и 3 составляет 77,3\%, однако соотношение стереоизомеров в смеси заметно меняется: в бо'льшем количестве образуется спирт 3 (66,1 \%), доля же изомера 2 в смеси падает до 33,2 \% (табл. 1). Разделение смеси изомеров 2 и 3 на индивидуальные формы проводилось колоночным хроматографированием на слабощелочной окиси алюминия. Элюент: эфир - гексан (1:1).

Установление пространственной структуры вторичных спиртов 2 и 3 проводили используя данные анализа их ПМР и ИК-спектров (табл. 2).

Таблица 2. Физико-химические и спектральные характеристики эпимеров $\underline{\mathbf{2}}$ и $\underline{\mathbf{3}}$

\begin{tabular}{|c|c|c|c|c|c|c|}
\hline \multirow{2}{*}{$\begin{array}{c}\text { Индекс } \\
\text { соединения }\end{array}$} & \multirow[t]{2}{*}{$\mathrm{R}_{\mathrm{f}}$} & \multirow{2}{*}{$\begin{array}{l}\text { Т. пл., } \\
{ }^{0} \mathrm{C}\end{array}$} & \multicolumn{2}{|c|}{ ИК-спектр, $v, c^{-1}$} & \multicolumn{2}{|c|}{ ПМР, $\delta$ от ТМС м.д. } \\
\hline & & & $\mathrm{C}-\mathrm{O}$ & $\mathrm{OH}$ & $\mathrm{H}^{4}$ & $\mathrm{OH}$ \\
\hline$\underline{2}$ & 0,30 & $118-119$ & 1048 & 3624 & 3,22 & 3,60 \\
\hline$\overline{3}$ & 0,38 & $143-144$ & 993 & 3628 & 3,80 & 3,40 \\
\hline
\end{tabular}

Данные спектра ЯМР ${ }^{1} \mathrm{H}$ показывает, что в обоих спиртах (르 и $\left.\underline{\mathbf{3}}\right)$ сохраняется конформация исходного аминокетона (). Определение ориентации гидроксильной группы в эпимерных по $\mathrm{C}^{4}$ спиртах 2 и 3 проводились на основании анализа КССВ протона $\mathrm{H}^{4}$ с вицинальными. Самым слабопольным сигналом протонов пиперидинового кольца является сигнал протона $\mathrm{H}^{4}$, из которого находили величины ${ }^{2} \mathrm{~J}_{\mathrm{H}}{ }^{3}{ }^{5}-$ две из них для спирта $\underline{2}$, составляют $12,1 \Gamma u$, что говорит о наличии двух аксиально-аксиальных взаимодействий. Следовательно, протоны при $\mathrm{C}^{4}$ и $\mathrm{C}^{5}$ расположены аксиально, а гидроксильная группа ориентирована экваториально. Сравнение характеристик ПМР спектров спирта $\underline{\mathbf{2}}$ и его эпимера $\underline{\mathbf{3}}$ показывает, что сигнал протона $\mathrm{H}^{5}$ спирта $\mathbf{3}$ сместился в слабое поле до $\delta 3,7$ м.д, а ${ }^{2} \mathrm{~J}_{\mathrm{H} \mathrm{H}}{ }^{3}$ стали меньше - 2,8 и 3,1 Гц, соответственно. Эти данные свидетельствуют о том, что протон $\mathrm{H}^{4}$ в спирте $\underline{\mathbf{3}}$ занимает экваториальное, а ОН группа - аксиальное положение.

Выводы о пространственной ориентации заместителей при $\mathrm{C}^{4}$ в эпимерных спиртах $\underline{\mathbf{2}}$ и $\underline{\mathbf{3}}$ подтверждаются данными ИК-спектроскопии. Известно, что у аксиальных спиртов частоты валентных колебаний связей $\mathrm{C}-\mathrm{O}$ меньше, а ОН больше, чем у экваториальных на 2-7 см$^{-1}$ [4-8]. В соответствие с этим, сравнение величин $v_{\mathrm{OH}}$ в ИК-спектрах указывает на то, что гидроксильная группа в $\underline{\mathbf{2}}\left(3624 \mathrm{~cm}^{-1}\right)$ ориентирована экваториально, а в $\underline{\mathbf{3}}\left(3628 \mathrm{~cm}^{-1}\right.$, узкая полоса) - аксиально.

Таким образом, определение количественного соотношения и пространственного строения эпимерных вторичных спиртов $\underline{\mathbf{2}}$ и $\underline{\mathbf{3}}$, полученных в различных условиях, позволяет сделать некоторые выводы о стерической направленности присоединения водорода к аминокетону $\underline{\mathbf{1}}$. Восстановление натрием в спирте, боргидридом натрия и каталитическое гидрирование приводит к образованию эпимерных вторичных спиртов с явным преобладанием спирта с экваториальной ОН группой. Совершенно иная картина наблюдается при восстановлении изопропилатом алюминия: в этом случае преимущественно образуется аксиальный спирт $\underline{\boldsymbol{3}}$. Отсюда следует, что стереохимический итог реакции восстановления зависит от природы восстанавливающего агента.

\section{ЭКСПЕРИМЕНТАЛЬНАЯ ЧАСТЬ}

Синтез стереоизомеров 1-метил-2-фенилдекагидрохинолин-4-олов $(\underline{\mathbf{2}}, \underline{\mathbf{3}})$

a) Восстановление натрием в спирте. В круглодонную колбу, снабженную обратным холодильником и мешалкой поместили раствор 5,0 г (0,021 моля) аминокетона $\underline{\mathbf{1}}$ в 125 мл этанола. К раствору при перемешивании небольшими порциями в течение 1 ч. прибавили $\overline{13}, 0$ г металлического натрия и нагревали при $90-95^{\circ} \mathrm{C}$ до полного растворения натрия. Реакционную смесь при охлаждении льдом обработали 60 мл конц. соляной кислоты. Спирт отогнали в вакууме водоструйного насоса, остаток растворили в воде и обработали избытком поташа. Основание экстрагировали эфиром, сушили поташом, эфир отогнали. Получено: 4,10 г (81,3\% от теории) смеси изомеров 2 и 3 с $\mathrm{R}_{\mathrm{f}} 0,30$ и 0,38 .

б) Восстановление боргидридом натрия. К смеси 1,0 г $(0,0025$ моля $) \mathrm{NaBH}_{4}$ в 50 мл изопропанола при перемешивании медленно добавляли раствор 2,5 г (0,001 моля) аминокетона 1 в 125 мл абсолютного изопропанола. Затем реакционную смесь перемешивали при $70-75^{\circ} \mathrm{C}$ в течение 2,5 , растворитель отгоняли, остаток подкисляли разбавленной $(1: 1)$ соляной кислотой. Воднокислый раствор подщелачивали избытком поташа, основание многократно экстрагировали эфиром и 
сушили сульфатом магния. Эфир отогнали и получили 2,3 г (91,4 \% от теории) кристаллической смеси эпиммеров (믄

Разделение эпимерной смеси (2 и 3) на индивидуальные формы. 3 г смеси изомерных аминоспиртов (2 и 3$)$ растирали с $82 \mathrm{Al}_{2} \mathrm{O}_{3}$ и хроматографировали на колонке высотой $80 \mathrm{~cm}$ и диаметром 2,5 cм, содержащей 500 г слабощелочной окиси алюминия. Элюентом служил эфир, пробы отбирали по 10-15 мл. После разделения и отгонки эфира получали 0,51 г $(17,1 \%$ от общего количества смеси) спирта $\underline{3}$ с т.пл. $143-144^{\circ} \mathrm{C}$ (из эфира), $\mathrm{R}_{\mathrm{f}}$ и 0,38 и 2,40 г $(80,8 \%$ от общего количества смеси спирта $2 \underline{2}$ с т.пл. $118-119^{\circ} \mathrm{C}$ (из эфира), $\mathrm{R}_{\mathrm{f}} 0,30$.

Найдено, 2 \%: С 77,98; Н 9,76; N 5,13. C $_{16} \mathrm{H}_{23}$ NO. Вычислено, \%: С 78,32; Н 9,45; N 5,71.

Найдено, $\underline{\mathbf{3}}$ \%: С 78,54; Н 9,15; N 6,01. $\mathrm{C}_{15} \mathrm{H}_{23} \mathrm{NO}$. Вычислено, \%: С 78,32; Н 9,45; N 5,71.

в) Каталитическое восстановление никелем Ренея. После наыщения водородом 0,5 г свежееприготовленного «скелетного» никеля добавили 1,0 г (0,004 моля) аминокетона 1 в 50 мл абс. Этаноле. После окончания реакции, отогнав растворитель 0,95 г (95\%) смеси эпимеров $\underline{\mathbf{2}}$ и $\underline{\mathbf{3}}$.

г) Восстановление изопропилатом алюминия. К смеси 0,68 г $(0,01$ моля) изопропилата алюминия в 25 мл абсолютного изопропанола приливали раствор 2,5 г (0.01 моля) аминокетона $\underline{1}$ в 125 мл абс. изопропанола. Реакционную смесь при перемешивании нагревали 24 ч при $70-75{ }^{\circ} \mathrm{C}$, изопропанол отогнали, остаток растворили в воде, обрабатывали избытком поташа, продукты реакции экстрагировали эфиром и сушили сульфатом магния. После удаления растворителя получали 1,99 г (78,8 \%) кристаллической смеси изомеров вторичного спирта $(\underline{\mathbf{2}}, \underline{\mathbf{3}})$, которую разделяли на индивидуальные формы колоночной хроматографией по описанной выше методике.

Образцы вторичных спиртов $\underline{\mathbf{2}}$ и $\underline{\mathbf{3}}$, полученные в различных опытах, не показывали депрессию температуры плавления в пробе смешения между собой.

\section{Литература}

1. Жилкибаев О.Т., Пралиев К.Д., Рожнов В.Б., Соколов Д.В. Стереохимия азотистых гетероциклов. VI. Стереоизомерия 2-фенилдекагидрохинолона-4// Изв. АН КазССР. Сер.хим. - 1985. - № 1. - С. 55-59.

2. Жилкибаев О.Т., Пралиев К.Д.,Клепикова С.Г. Пространственное строение стереоизомеров 2фенилдекагидрохинолин-4-она // Труды Межд. конф. «Состояние и перспективы развития органической химии в РК». - Алматы, 2002 г. - С. $113-115$.

3. Жылқыбаев О.Т., Пірәлиев Қ.Ж. 3-Фенил-2-азабицикло[4.4.0]-декан-5-онды тотықсыздандыру// Изв. НАН РК. Сер. хим. - 2007. - № 1. - С. $92-94$.

4. Demarco P.V., Parcas E., Dollerell D. Pyridine indused solvent shifts in the nuclear magnetic resonance spectra of hydroxylic compaunds // J.Am. Chem. Soc. - 1968. - Vol. 90. - P. $5480-5486$.

5. Luts E.T.G., van der Maas I.H. Structural informftion from $\mathrm{OH}$ stretching frequencies. VII. Prefential $\mathrm{OH}$ rotamers in saturated tertiary alcohols // Spectrochim. Acta. - 1982. - Vol. 37A. - N 8. - p. $693-697$.

6. Van der Maas I.H., Luts E.T.G. Structural informftion from $\mathrm{OH}$ stretching frequencies. X. OH rotamer in tertiary cyclohexanols // Spectrochim. Acta. - 1982. - Vol. 38A. - N 8. - p. $927-931$.

7. Илиел Э., Аллинжер Н., Энжиал С., Моррисон Г. Конформационный анализ. М.: Мир. 1969. 592 с.

\section{1-МЕТИЛ-2-ФЕНИЛДЕКАГИДРОХИНОЛИН-4-ОНДЫ ТОТЫҚСЫЗДАНДЫРУ}

\section{о.Т. Жылқыбаев}

1-Метил-3e-фенил-транс-декагидрохинолин-4-онды түрлі тағдайларда тотықсыздандырудың стереохимиясы зерттелді: этанолдағы натриймен тотықсыздандырғанда бұл реакцияның механизміне сәйкес негізінен экваториалды спирт түзіледі; натрий боргидридімен және катализдік гидрлегенде - экваториалды эпимердің басымдылығымен аминоспирттердің қоспасы түзіледі; алюминий изопропилатымен тотықсыздандыру - бұл әдістің әдеттегі бағытталуы бойынша жүріп — аксиалды спирттің басымдылықпен түзілуіне әкеледі.

\section{REDUCTION OF 1-METHYL-2-PHENYLDECAHYDROQUINOLIN-4-ONE}

\section{O.T. Zhilkibayev}

Stereochemistry of the reduction of 1-methyl-2e-phenyl-trans-decahydroquinoline-4-one has been studied under different conditions: the reduction by sodium in ethanol in accordance with the mechanism of this reaction gives mainly an equatorial alcohol; with sodium boron hydride - there forms a mixture of aminoalcohols with the predominance of an equatorial epimer; the reduction of aminoketone by aluminum isopropylate proceeds with the direction, usual for this method, and results in the predominant formation of axial alcohol. 